\title{
The Practical Teaching Methods of Arabic Language at female's Mosque in Henan Province - China
}

\author{
Li Qing Mei \\ Sultan Idris Education University \\ Suo Yan Mei \\ Sultan Idris Education University \\ Nazri Bin Atoh
}

\section{Abstract}

Teaching methods for languages especial for Arabic language for non-native speakers always discussed by researchers, and the teaching methods for Arabic language at the female's mosque of Henan Province, china still based on the traditional method without any update, but no one of researchers focused on this issue. however, this research aims to investigate the teaching method of Arabic language teaching in the female's mosque of Henan of china to fill up the gap of research filed of teaching Arabic for non-native speakers. The study used the descriptive method to explore new information on Arabic teaching in China. and it was based on the field curriculum to highlight the teaching methods applied by female teachers when teaching Arabic at female mosques, analytical methods to analysis the Data collection which designed by questionnaires which distributed to 10 female teachers the five mosques for female's Mosque in Henan Province China. The method of data analysis is percentage and frequency method using SPSS system. The research found that: teachers don't have any clear ideal about teaching method for teaching Arabic language, and majorly of them only use translation and Grammar Method to teach Arabic. there are many aspects need to be improved. Hence, the researcher presented some recommendations and suggestions to improve the curriculum and methods of teaching Arabic language in mosques for female in Henan Province, China.

Keyword: teaching method, female's mosque, teaching Arabic

\section{Introduction}

With Islam came to China by the hands of Arab Muslim merchants, preachers, and soldiers over 1300 years ago, and Arabic language came together with Islam to china. Chinese Muslims had great interest for the Arabic language from ancient times to the present. Historically, Sheikh Imam (HuDengzhou) Muhammad Abdullah Ilyas (1522-1597 CE) invented a special method of teaching Arabic and Islamic studies at male mosques in China. In the late Ming (1368-1644 AD) and early Qing (1644-1912 AD) began teaching Islam and Arabic for female Muslim at the female School. from that time, the female Mosque had established, and those 
mosques only open for female Muslim for pray and study Islam and Arabic. (Dingjun, 2006, Pang shi qian (1937).

The ancient and contemporary scholars discussed about teaching the Arabic language in the mosques for men, schools, institutes and universities in China and there is no one deals with the methods of teaching Arabic at female' mosques. This research deals with the teaching methods of Arabic language at the 5 Females' mosques in Henan Province of China, and the teaching methodology for Arabic language at the female's mosque of Henan Province, china still based on the traditional method without any update, but no one of researchers focused on this issue.

By observation of researchers, female Muslim at mosques have a desire to learn Arabic. Through the teachers to teach them Arabic, they try to learn and master this language to achieve their lofty goal and noble purpose, i.e .: reading the Qur'an, memorizing some surahs from it, memorizing some daily supplications, and understanding the meaning of Qur'an and Islam well.

The researcher has found that many female students at female 's mosques of do not speak Arabic in general, and they are unable to speak Arabic. Accordingly, the researcher believes that this problem relates to the shortcomings in the teaching methods that are used by Arab language teachers at female's mosques.

The researcher has noted that the problems in teaching and learning the Arabic language as a following matters:

1. The educational methods in the Arabic language in mosques for female in Henan Province, China, use the reading method and the grammar and translation method. These methods are among the oldest educational methods. Do not use direct, oral, or communicative. Teaching Arabic in mosques for female focuses only for reading skill, and it almost does not focus on three other skills: listening, speaking, and writing, so these three skills among students in mosques are very weak.

2. The willingness of female teachers to perform teaching is incomplete because they need extensive courses and training to strengthen their knowledge of the Arabic language and teaching methods.

The motivations that prompted the researchers to choose this topic are:

1. Introducing the educational methods offered by the mosques to their students and clarifying the nature of the subjects they study and presenting more important proposed topics by which we replace those old method.

2. female's Mosques play an important role in the academic and religious life of female Muslim, and no one talks about the methods of teaching the Arabic language in general and about the methods of teaching Arabic at female's Mosques. And To fill this gap, the researchers' interest to write this topic.

In sum, the researchers believes that the methods of teaching $t$ Arabic language used at female's Mosques need to be analysed in order to improve the performance of female students in learning the Arabic language and prepare them to continue their studies in the primary and higher levels. Accordingly, the researchers will conduct an analytical and descriptive study of the methods of teaching Arabic as a second language and the role of female teachers in it. 


\section{Research objects}

This research aims to:

Investigate the. Historical background of teaching Arabic at female mosque.

Explore the teacher's background of Arabic at female's mosques.

Discover the types of teaching methods which used by teachers in the female's mosques.

\section{Limitation of research:}

The research is focused on teaching methods of teaching Arabic language by the female teachers at 5 female's mosques in Henan Province of China, it descriptive and analytical study the teaching methods which applied by female teachers at 5 mosques of henan province , china namely the Nanyang Station female's Mosque, Wuzhi Wom female en's Mosque, Xinxiang East Female's Mosque, Ge Dang Dian Female's Mosque, and Sangpo Zhang Female's Mosque. Moreover, the researchers conducted face-to-face, semi-structured interviews interviewed 10 females' teachers and observes one session for each mosque. This session has 45 minutes. The data will be collected from them and will be analysed and evaluated.

\section{Research Method:}

This research presents both the quantitative and qualitative analyses of data collected. For the quantitative part, data were analysed using SPSS version 13.0; this includes descriptive analyses of female teachers 'data. For the qualitative part, triangulation method was used to analyse the qualitative data for the interviewed participants. the face-to-face, semi-structured interviews interviewed 10 females' teachers from 5 females 'mosques in Henan Province of China, namely the Nanyang Station Female's Mosque, Wuzhi Female's Mosque, Xinxiang East Female's Mosque, Ge Dang Dian Female's Mosque, and Sangpo Zhang Female's Mosque and observes one session for each mosque. This session has 45 minutes. The data will be collected from them. the descriptive analysis will apply to analysis Frequency, percentage and means of items of questioners.

\section{Discussion and Finding:}

The discussion divided into 2 parts: first part convers general information about female teachers at 5 female's mosques of Henan province, china. Second part included 12 questioners about teaching methods which applied by the teachers from 5 female's mosques in Henan province of china. .

\section{General information about female teachers at 5 female's mosques in Henan province of China}

Category frequencies of the demographic variables which are age of participant, first language, Academic qualifications, Period of Teachers' Experiences, and language used for teaching Arabic language. The table 1 shows that majority of teachers $(n=5,50 \%)$ are between the ages of (36-45) years and these indicate that these teachers at female's mosques have teaching experience available for the Arabic language and the rich experience in life. In relation to the first language of the participants, the analysis indicated that $(n=10,100 \%)$ of their language were Chinese. However, the Academic qualifications for participants were majority of them holed lower certificate $(n=9,90 \%)$, and only $(n=1,10 \%)$ of them holed bachelor level . Moreover, the analysis showed that more than one-third of the participants had more than 6 
years teaching experiences. The analysis also shown that majority of the participants $(60 \%, \mathrm{n}$ =6) used Henan dialect to teach Arabic language.

Table 1. Distribution of Respondents according to their General information

\begin{tabular}{|c|c|c|c|}
\hline & Characteristics & $n$ & $\%$ \\
\hline \multirow[t]{6}{*}{ Age } & $25-30$ & 2 & $20 \%$ \\
\hline & $31-35$ & 1 & $10 \%$ \\
\hline & $36-40$ & 2 & $20 \%$ \\
\hline & $41-45$ & 3 & $30 \%$ \\
\hline & $46-50$ & 1 & $10 \%$ \\
\hline & $51-55$ & 1 & $10 \%$ \\
\hline \multirow{2}{*}{$\begin{array}{l}\text { First language (mother } \\
\text { tongue) }\end{array}$} & Chinese & 10 & $100 \%$ \\
\hline & Arabic & 0 & $0 \%$ \\
\hline \multirow{5}{*}{$\begin{array}{l}\text { Academic } \\
\text { qualifications }\end{array}$} & Junior Certificate & 5 & $50 \%$ \\
\hline & High School & 4 & $40 \%$ \\
\hline & Bachelor & 1 & $10 \%$ \\
\hline & Masters & 0 & $0 \%$ \\
\hline & Doctorate & 0 & $0 \%$ \\
\hline \multirow{4}{*}{$\begin{array}{l}\text { Period of Teachers' } \\
\text { Experiences }\end{array}$} & $1-5$ years & 3 & $30 \%$ \\
\hline & $6-10$ years & 2 & $20 \%$ \\
\hline & 11-15years & 2 & $20 \%$ \\
\hline & More than 15 years & 3 & $30 \%$ \\
\hline \multirow{3}{*}{$\begin{array}{l}\text { language used for } \\
\text { teaching Arabic } \\
\text { language }\end{array}$} & Arabic & 0 & $0 \%$ \\
\hline & $\begin{array}{l}\text { Standard Chinese } \\
\text { Language }\end{array}$ & 4 & $40 \%$ \\
\hline & Chinese henan dialect & 6 & $60 \%$ \\
\hline
\end{tabular}

\section{Teaching methods applied by female teachers to teach Arabic at female' mosques}

The relevant discussion to the Teaching methods applied by female teachers from 5 female's mosques of Henan province, china was contained 12 distinctive items, the descriptive analysis is used to carry this study. When these teachers were asked about their Teaching methods which they applied to teach Arabic at female's mosque, out of expectation that there are $100 \%$ of teachers $(n=10)$ said that they use some of the teaching methods to teach Arabic for nonnative speakers, The mean of item 1 is 4.20 . from this result, we can see that same like they are expertise in teaching methods, maybe they themselves don't know well what are the teaching methods. 
On the other hand, $100 \%(\mathrm{n}=10)$ of them prefer the grammar and translation method, as it facilitates the teaching Arabic language for non-native speakers. The mean of the item is 4.20. Based on this result, the study sample from all teachers interested in using the grammar and translation method during their Arabic teaching. It is known that this method at mosque is considered one of the most famous methods, and it is the method that was followed by male and female teachers at mosques to teach Arabic language from the past centuries to the present day. This method has advantages and disadvantages and still argue for it between scholars.

In addition, $60 \%(\mathrm{n}=6)$ of the participant mentioned that they were delivered specific topic by an oral teaching method against $40 \%(n=4)$ while another $0 \%(n=0)$ were undecided. The mean is 3.60. Based on these results, the researchers noted that majority of teachers considered that the use of the automatic method to teach the Arabic language, but some do not consider that they always use of this method to teach Arabic language.

Amazingly $80 \%(n=8)$ of selected teachers confirmed that applied analytical method to teach Arabic to enhance the students' reading skills of words and complete sentences., only $10 \%$ (n $=1$ ) disagreed that, while $10 \%(\mathrm{n}=1)$ were unsure. The mean of this item is 3.90. according to this result, the higher percentage of female teachers at mosques like to use the analytical (college) method to establish reading words and complete sentences and analyse students for vocabularies, syllables, and letters. It begins by teaching the words before the letters, as they are the opposite of the syntactic (partial) method.

On the other hand, $90 \%(\mathrm{n}=9)$ of the teachers mentioned that they read a topic from the textbook to train students for listening skill, $10 \%(\mathrm{n}=10)$ were uncertain about this statement, The mean of this item is 4.50 . Based on this result, the researchers realized that majority of teachers agreed to train female students' listening skill by reading the test book only without depends on technology. As Samak $(1970,245)$ confirmed that the teacher trains his pupils for listening skill to read a topic to them and a story he has received In an audio reading, and they depend on his awareness of their ears and their minds without looking at a book, and then discusses with them about what they have heard."

Contrarily, $100 \%(n=10)$ of the participants asked students to read silent for the textbook during the class, the mean is 4.20 . Based on this result, all teachers interested in using the silent reading method to develop the students' reading skill. This type of reading has become very necessary for our lives, due to the many situations that require it, such as: reading newspapers and magazines, reading private messages, reading for quick review before exams, reading in public libraries, as well as meeting students in the classroom to remember and review often. Samak $(1975,249)$ stated that the special reading skill can be developed by the method of silent reading more than it can be by the method of outright reading and deals with these four basic aspects: 1 - the perception of the word. 2 - the perception of the meaning. 4The aspect of the correlation of what the reader realizes new experiences with his old experiences, and it has been shown that the silent type of reading develops these aspects more and faster than what happens in the stereotype. As well as, silent reading can attract the attention for understanding.

Same as last statement, there are $100 \%(n=10)$ of the teachers selected the statement which is asked students to read loudly for the textbook during the class, the mean of the item is 4.30 . this result indicated that all female teachers used the standard reading method when they teach Arabic. The teachers are preferred reading loudly for the beginners of Arabic language 
learners with sufficient interest and abundant of them, and making them a good basis for training female students, by this method, teachers can reveal female students 'speech difficulties and their faults. Every day, the student practice to read text in Arabic loudly, so their ability to reading skill, quality of pronunciation, and representation of meaning can increase.

Nonetheless, more than half of participants $60 \%(n=6)$ agreed that they don't use the direct method to teach Arabic for the students, and only $10 \%(n=1)$ disagreed about this statement, while $30 \%(n=30)$ were uncertain. The mean of the item is 4.6. this result shows that high percentage of the teachers do not choose the direct method to teach female students. The direct method is intended to use the target language (the Arabic language) to teach the Arabic language and a violation of the grammar and translation method. As Zakaria $(23,2016)$ discussed that the direct method aims to teach the concepts of the new language in real situations so that the direct link between the linguistic symbol and its significance is related to the same thing or the image and the movement, without using the student's language or another language that he knows.

When it comes to use the communicative method to teach Arabic to the students, majority of them $80 \%(n=8)$ mentioned that they don't use the communication method to teach Arabic for their students, and $20 \%(n=2)$ of them are unsure about this statement, the mean of the item is 4.70. from the result above, the researchers believed that the main reason is the teachers who prefer and enjoy in using the translation method and neglects the use of the Arabic language in the process of teaching Arabic language. Of course, Arabic communication teaching requires qualified teachers in every aspect of educational, personal, and language skills, in addition to her desire for education. Teaching the Arabic language will be effective if the education is conducted in an interesting and Arab atmosphere. And this atmosphere needs the teachers to synthesize the Arab environment, and the artificial Arabic environment is the environment of learning the second language in the classroom, which is a conscious acquisition of the second language. Therefore, to activate the acquiring Arabic language teaching, the teachers should create the Arab environment in the classroom and outside by carrying out Arabic language activities from Arab representation and others , as Rushdi (1989) emphasized that speaking in the second language is one of the basic skills that are among the goals of linguistic studies, even the students communicate with others.

Very wonder that $100 \%$ of the participants applied only unit method to teach reading skill and grammar by using textbook. The mean of this item is 4.30 . When the teacher applies the unit method in teaching Arabic, she follows the following steps: 1 . Take the text and draw the students 'attention to the text. 2 . Show them the content of the text with an interesting introduction. 3. Than read the text, usually to develop the listening skill. 4. Choose a few female students to read the text loudly, so that each of them reads it if the time enough; and each reads a portion of the text when the time is not sufficient. Then teacher corrects their mistakes if she finds. 5. Explain vocabulary, phrases, and structures that students do not know. 6. Discuss morphological and grammatical rules and their application and preservation. 7. Assign students to write some vocabulary and words or assign them train to answers general questions about the text. This method has been used from ancient times to the present day at all mosques of the Hui people in China. The unit method of teaching languages depends on psychological, pedagogical and linguistic foundations. As Al-Rikabi (1996) asserted that It is a psychological basis that it renews the activity of students and sends their longing and pays for them boredom and boredom, because of the diversity of work and its coloration, and that it 
proves understanding through repetition and referring to the same subject for its treatment in various aspects, and that it moves from the whole to the part, and this goes hand in hand The nature of the mind in the awareness of things and information,

However, majority $70 \%(n=7)$ of the teachers don't train the students to be expert in writing skills in Arabic language, and 10\% ( $\mathrm{n}=1)$ of them trained their students to be expert in writing skills in Arabic language. While 20\% ( $n=2)$ of them unsure about this statement, the mean of this item is 2.3. this result shows that majority of teachers thought the students to write the drawing of Arabic letters after completing the teaching of letter sounds. And the teacher always asks them to write it more. At the end of the lesson, the female students submit the notebooks to the teacher, and she examines their writing in drawing letters and words after the semester.

\begin{tabular}{|c|c|c|c|c|c|c|}
\hline Item & $S A$ & $A$ & $U$ & $D$ & $S D$ & Mean \\
\hline $\begin{array}{l}\text { I use some teaching methods to teach Arabic } \\
\text { for non- native speakers }\end{array}$ & $\begin{array}{l}3 \\
(30 \%)\end{array}$ & $\begin{array}{l}7 \\
(70 \%)\end{array}$ & $\begin{array}{l}0 \\
(0 \%)\end{array}$ & $\begin{array}{l}0 \\
(0 \%)\end{array}$ & $\begin{array}{l}0 \\
(0 \%)\end{array}$ & 4.20 \\
\hline $\begin{array}{l}\text { I prefer the grammar and translation method, } \\
\text { as it facilitates the teaching of the Arabic } \\
\text { language for non-native speakers. }\end{array}$ & $\begin{array}{l}2 \\
(20 \%)\end{array}$ & $\begin{array}{l}8 \\
(80 \%)\end{array}$ & $\begin{array}{l}0 \\
0 \%)\end{array}$ & $\begin{array}{l}0 \\
(0 \%)\end{array}$ & $\begin{array}{l}0 \\
(0 \%)\end{array}$ & 4.20 \\
\hline $\begin{array}{l}\text { I was delivered specific topic by an oral teaching } \\
\text { method. }\end{array}$ & $\begin{array}{l}5 \\
(50 \%)\end{array}$ & $\begin{array}{l}1 \\
(10 \%)\end{array}$ & $\begin{array}{l}0 \\
(0 \%)\end{array}$ & $\begin{array}{l}3 \\
(30 \%)\end{array}$ & $\begin{array}{l}1 \\
(10 \%)\end{array}$ & 3.60 \\
\hline $\begin{array}{l}\text { I applied analytical method to teach Arabic to } \\
\text { enhance my students' reading skills of words } \\
\text { and complete sentences. }\end{array}$ & $\begin{array}{l}2 \\
(20 \%)\end{array}$ & $\begin{array}{l}6 \\
(60 \%)\end{array}$ & $\begin{array}{l}1 \\
(10 \%)\end{array}$ & $\begin{array}{l}1 \\
(10 \%)\end{array}$ & $\begin{array}{l}0 \\
(0 \%)\end{array}$ & 3.90 \\
\hline $\begin{array}{l}\text { I read a topic from the textbook to train students } \\
\text { for listening skill }\end{array}$ & $\begin{array}{l}6 \\
(60 \%)\end{array}$ & $\begin{array}{l}3 \\
(30 \%)\end{array}$ & $\begin{array}{l}1 \\
(10 \%)\end{array}$ & $\begin{array}{l}0 \\
(0 \%)\end{array}$ & $\begin{array}{l}0 \\
(0 \%)\end{array}$ & 4.50 \\
\hline $\begin{array}{l}\text { I asked students to read silent for the } \\
\text { textbook during the class }\end{array}$ & $\begin{array}{l}2 \\
(20 \%)\end{array}$ & $\begin{array}{l}8 \\
(80 \%)\end{array}$ & $\begin{array}{l}0 \\
(.0 \%)\end{array}$ & $\begin{array}{l}0 \\
(0 \%)\end{array}$ & $\begin{array}{l}0 \\
(0 \%)\end{array}$ & 4.20 \\
\hline $\begin{array}{l}\text { I asked students to read loudly for the } \\
\text { textbook during the class }\end{array}$ & $\begin{array}{l}3 \\
(30 \%)\end{array}$ & $\begin{array}{l}7 \\
(70 \%)\end{array}$ & $\begin{array}{l}0 \\
(.0 \%)\end{array}$ & $\begin{array}{l}0 \\
(0 \%)\end{array}$ & $\begin{array}{l}0 \\
(0 \%)\end{array}$ & 4.30 \\
\hline $\begin{array}{l}\text { I don't use the direct method to teach Arabic for } \\
\text { my students }\end{array}$ & $\begin{array}{l}1 \\
(10 \%)\end{array}$ & $\begin{array}{l}5 \\
(50 \%)\end{array}$ & $\begin{array}{l}3 \\
(30 \%)\end{array}$ & $\begin{array}{l}1 \\
(10 \%)\end{array}$ & $\begin{array}{l}0 \\
(0 \%)\end{array}$ & 4.60 \\
\hline $\begin{array}{l}\text { I used Oral audio method occasionally to teach } \\
\text { Arabic language for recordings, communication, } \\
\text { and dialogue. }\end{array}$ & $\begin{array}{l}0 \\
(0 \%)\end{array}$ & $\begin{array}{l}8 \\
(80 \%)\end{array}$ & $\begin{array}{l}1 \\
(10 \%)\end{array}$ & $\begin{array}{l}1 \\
(10 \%)\end{array}$ & $\begin{array}{l}0 \\
(0 \%)\end{array}$ & 4.70 \\
\hline $\begin{array}{l}\text { I do not use the communicative method to teach } \\
\text { Arabic to my students. }\end{array}$ & $\begin{array}{l}0 \\
(0 \%)\end{array}$ & $\begin{array}{l}8 \\
(80 \%)\end{array}$ & $\begin{array}{l}2 \\
(20 \%)\end{array}$ & $\begin{array}{l}0 \\
(0 \%)\end{array}$ & $\begin{array}{l}0 \\
(0 \%)\end{array}$ & 4.70 \\
\hline $\begin{array}{l}\text { I applied only one unit of method to teach } \\
\text { reading skill and grammar by using } \\
\text { textbook. }\end{array}$ & $\begin{array}{l}3 \\
(30 \%)\end{array}$ & $\begin{array}{l}7 \\
(70 \%)\end{array}$ & $\begin{array}{l}0 \\
(.0 \%)\end{array}$ & $\begin{array}{l}0 \\
(0 \%)\end{array}$ & $\begin{array}{l}0 \\
(0 \%)\end{array}$ & 4.30 \\
\hline
\end{tabular}




\begin{tabular}{|l|l|l|l|l|l|l}
\hline $\begin{array}{l}\text { I trained students to be expert in writing } \\
\text { skills }\end{array}$ & $\begin{array}{l}0 \\
(0 \%)\end{array}$ & $\begin{array}{l}1 \\
(10 \%)\end{array}$ & $\begin{array}{l}2 \\
(20 \%)\end{array}$ & $\begin{array}{l}6 \\
(60 \%)\end{array}$ & $\begin{array}{l}1 \\
(10 \%)\end{array}$ & 2.30 \\
\hline
\end{tabular}

Table 2 : Frequency, percentage and means of types of teaching methods applied by female teachers

\section{Conclusion}

The research found that majority teachers at female's mosques at He Nan province of china don't have any clear ideas about teaching method for teaching Arabic language, and majorly of them only use translation and Grammar Method to teach Arabic. Since no one of them didn't train properly as an educators or expert in teaching methods. And the researchers believes that the methods of teaching t Arabic language used at female's Mosques need to be analysed in order to improve the performance of female students in learning the Arabic language and prepare them to continue their studies in the primary and higher levels. Accordingly, there are many aspects need to be improved. Hence, the researcher presented some recommendations and suggestions to improve the curriculum and methods of teaching Arabic language in mosques for female in Henan Province, China

1, encourage researchers to do more researches about the issue on teaching method for Arabic language teaching at mosques in china

2.suggested to send some expertise to train those teachers to be formula about teaching method to teaching Arabic language.

3. suggested to review back the textbook in Arabic language to confirm the that is suitable for the students.

\section{References}

[1] Ding jun (2006). Zhong guo a la bo yu jiao yu shi gang. Beijing: Zhong guo she hui ke xue chu ban she.

[2] Hu yun sheng (2011). Kai feng shi yi si lan jiao qing zhen si, Kai feng wen shi zi liao.

[3] Madkura, Ali Ahmad(2010) teaching methods of Arabic language. Oman: dara almasir

[4] Maaruf, Nayif mahmud(1998) characteristics of Arabic and it's teaching methods. Lubnan: Dara Nafa'yis

[5] Pang shi qian (1937). Zhong guo hui jiao si yuan jiao yu zhi yan ge ji ke ben, Shu gong ban yue kan di qi juan di si qi.

[6] Samak, muhamad solih(1975). Art of teaching Arabic, Its Behavioral Impressions, and Practical Patterns. Egypt: The Anglo Egyptian Library

[7] Samsa't, Ahmad Al-hasan (2020) Educational programs for the Arabic language: methods and teaching methods (teacher training), Malaysia: international Islamic university

[8] Zakaria, Jama'l Abdul Na'sir (2016) introduction of teaching Arabic language for nonnative speakers: Methods and understanding. Malaysia: international Islamic university. 